\title{
Reading the Songs of the Sabbath Sacrifice
}

\author{
Observations on Material, Layout, and Text
}

Reading is a social mode of reception of a script-bearing artifact. Whereas by no means all writing was and is meant to be read, ${ }^{1}$ the scribal production and reproduction of literary compositions-in a broad sense-aimed and aim at being read. Dealing with ancient manuscripts that show literary compositions, two dimensions of reading come to mind: first, reading ancient manuscripts in a present-day scholarly perspective, and second, asking about the reading practices of the ancient readers. In the first context, one could evaluate the state of preservation of the manuscripts, the possibilities for reconstruction, the variances ("readings") between different manuscripts, et cetera. In the second direction of research, one is asking about the modes of reception in the historical and social contexts from which the documents were produced. The first dimension is mainly the concern of editions of ancient manuscripts. Since the manuscripts of interest in this paper are all published in several editions from the last thirty years, ${ }^{2}$ I can focus on the second question, the ancient reading practices.

But since reading-as most practices of reception-is a momentary act, that only rarely leaves marks in the manuscripts themselves, it is almost impossible to explore ancient modes of reading from the manuscripts that have been or can be assumed to have been read. What is accessible for research, however, are hints about intended modes of reading and reception in the documents themselves. Such hints might be found in the texts. However, codicological features of the manuscripts, for example, the choice of material, its preparation for the act of writing, and the design and the layout of the script can perhaps better shed light on the intended reading of the concrete document than the text itself. ${ }^{3}$ Along these lines, the present paper analyzes the manuscripts of the early Jewish Songs of the Sabbath Sacrifice that were found among the Dead Sea Scrolls by considering not only the scholarly editions of the texts, but

1 See e. g. the various examinations of restricted presence of writing in Frese/Keil/Krüger (eds.) 2014. 2 Newsom (ed.) 1985; Eshel et al. (eds.) 1998, 173-401; García Martínez/Tigchelaar/van der Woude (eds.) 1998, 259-304; Charlesworth/Newsom 1999; see also the following translation: Davila 2000, 83-167.

3 Cf. Snyder 2000, esp. 26f, 47f.

This publication originated in the Collaborative Research Centre 933 "Material Text Cultures. Materiality and Presence of Writing in Non-Typographic Societies" (subproject C02, UP2 "Between Literature and Liturgy: Pragmatics and Practices of Reception of Poetic and Liturgical Writings from the Judean Desert"). The CRC 933 is funded by the German Research Foundation (DFG). I would like to thank Anna Krauß (Heidelberg) and Mika Pajunen (Helsinki) for their helpful comments on a previous version of this paper, and James Tucker (Göttingen) for improving my English. 
also the images of the manuscripts, since the latter might reveal information relevant for this paper that are not recorded in the editions. In the first part, the composition and its manuscripts are presented, focused already on those aspects that can be evaluated as evidence for the ancient reading of the respective manuscripts. In the second part, further details of the manuscripts and their layout are analyzed-the transition between two songs, the empty spaces and lines (vacats) within one song, and the representation of the deity. Lastly, some textual aspects will be taken into account by searching for self-referential elements concerning the reception of the composition. As a conclusion, the results of the analysis of all three dimensions, the manuscripts, their layout, and the texts will be taken together to get a general view on the reading practices in Ancient Judaism using the example of the Songs of the Sabbath Sacrifice.

\section{The Manuscripts}

The so-called Songs of the Sabbath Sacrifice (שירות עולת השבתîrôt 'ôlat haššabbāt) are a sequence of thirteen songs originating in the late Second Temple Period of Ancient Israel. The title is adapted from the superscriptions of the individual sections of the composition. According to the superscriptions, the songs were intended for the first thirteen Sabbaths, i. e. the first quarter of the year. ${ }^{4}$

The collection is attested by fragments of seven-maybe eight-scrolls from cave 4 of Qumran, and another fragmented copy from cave 11; one more fragment was found within the fortress of Masada (tab. 1). ${ }^{5}$ Among those compositions that are not part of the (later) Biblical canon, only few have survived in such relatively high numbers. Thus, the mere number of copies found in the Judean Desert might already point to the importance of this composition for the yahad of Qumran ${ }^{6}$-and maybe also for Second Temple Judaism as a whole. Especially the evidence from Masada might indicate that the Širot were read not only within the yahad but in different groups among Second Temple Judaism, although it cannot be ruled out, that this manuscript originates in Qumran as well. ${ }^{7}$

4 On the superscriptions, see below, p. $80 \mathrm{f}$.

5 All extant copies of the Širot match the criteria for a "typical psalm or prayer collection" identified by Pajunen (in this volume, p. 58): written in Hebrew in a (semi-)formal hand on a leather/parchment manuscript with divisions between individual compositions.

6 Ever since the first editions of the composition, the connection between the Širot and the yahad is debated. While the Širot certainly were popular in Qumran-as can be seen from the number of extant manuscripts and the fact, that other (sectarian) compositions adopted aspects of content and style from them (cf. e. g. Charlesworth/Newsom 1999, 4f.)-their provenience is disputed. C. Newsom, who originally assumed the composition to be of sectarian origin (Newsom [ed.] 1985, 1-4), more recently argued in favor of a pre-Qumran provenience (Charlesworth/Newsom 1999, 4f). Others still regard a yahadic provenience more convincing (e. g. Rietz 2007, 49-52).

7 The assumed common Vorlage of Mas 1k and 4Q405 might lead in this direction, as well; cf. below fn. 48 . 
Tab. 1: The manuscripts of the Songs of the Sabbath Sacrifice.

\begin{tabular}{|c|c|c|c|c|}
\hline Siglum & Name & $\begin{array}{l}\text { Number of } \\
\text { Fragments }\end{array}$ & Paleographic Dating ${ }^{8}$ & $\begin{array}{l}\text { Content } \\
\text { (parts of songs) }\end{array}$ \\
\hline 4Q400 & 4QShirShabb ${ }^{a}$ & 7 & $75-50 \mathrm{BCE}$ & 1,2 \\
\hline 4Q401 & 4QShirShabb & 38 & $\sim 25 \mathrm{BCE}$ & $1,2,3,4,5,6$ \\
\hline 4Q402 & 4QShirShabb ${ }^{c}$ & 12 & $\sim 25 \mathrm{BCE}$ & 4,5 \\
\hline 4Q403 & 4QShirShabb & 3 & $25-1 \mathrm{BCE}$ & $6,7,8$ \\
\hline 4Q404 & 4QShirShabb & 25 & $\sim 25 \mathrm{BCE}$ & $6,7,8$ \\
\hline 4Q405 & 4QShirShabb & 105 & $\sim 50 \mathrm{BCE}$ & $6,7,8,9,10,11,12,13$ \\
\hline 4Q406 & 4QShirShabb & 5 & $?^{10}$ & $6 ?, 8 ?^{11}$ \\
\hline 4Q407 & 4QShirShabb ${ }^{\mathrm{h}}$ & 2 & $\sim 50 \mathrm{BCE} ?$ & $?^{12}$ \\
\hline 11Q17 & 11QShirShabb & 42 & $20-50 \mathrm{CE}$ & $7,8,9,10,11,12,13$ \\
\hline Mas $1 \mathrm{k}$ & MasShirShabb & 1 & $\sim 50 \mathrm{CE}$ (before $73 \mathrm{CE}$ ) & 5,6 \\
\hline
\end{tabular}

The fragmentary scrolls do obviously not preserve the entire composition. It is striking that the reconstruction for all manuscripts assumes that the respective fragments belong to subsequent songs of the cycle. Whereas the material evidence ${ }^{13}$ for these reconstructions is rather convincing in some cases, in other instances this assumption seems to be rather a presupposition. But even if it were true for all the manuscripts, the material evidence could not answer the question, whether all-or even any-of the manuscripts contained the complete cycle. ${ }^{14}$ While the passages attested by several manuscripts show some minor textual variants, by and large, the text of

8 According to Newsom (ed.) 1985; Eshel et al. (eds.) 1998.

9 As reconstructed by Carol Newsom (Newsom [ed.] 1985; Eshel et al. [eds.] 1998), all numbers in italic script refer to assignments labeled by her as (highly) probable or conjectural. For $11 \mathrm{Q} 17$ also García Martínez/Tigchelaar/van der Woude (eds.) 1998 has been consulted.

10 The few extant fragments of this scroll cannot be dated paleographically because the ink has eaten away parts of the leather. Thus, the writing can only be reconstructed from the shape of the holes which makes paleographic propositions impossible, cf. Eshel et al. (eds.) 1998, 395.

11 Some expressions on the fragments are typical for the sixth and the eighth song. But the ascription is debatable; cf. Eshel et al. (eds.) 1998, 395-398, see also below fn. 54.

12 The two small fragments exclusively contain words that can also be found elsewhere in the Širot. But since they do not show a superscription or other vocabulary limited to the Širot, the ascription is by no means certain; cf. Eshel et al. (eds.) 1998, 399-401.

13 I. e. especially the arrangement of fragments in their find-context or recurring forms of destruction (cf. e. g. for 4Q405 Eshel et al. [eds.] 1998, 309-311).

14 Only in the case of 4Q405 the editors even mention the possibility-or probability-of a scroll containing all thirteen songs; Eshel et al. (eds.) 1998, 311. 
the composition is stable. ${ }^{15}$ Also, the orthography is rather uniform between all the copies. ${ }^{16}$ However, the extant fragments of the scrolls reveal that they were rather different in regard to their material aspects, layout, and scribal character (tab. 2).

Tab. 2: Material Aspects of the Scrolls ${ }^{17}$

\begin{tabular}{|c|c|c|c|c|c|c|c|c|}
\hline \multirow[t]{2}{*}{ Scroll } & \multirow{2}{*}{$\begin{array}{l}\text { Height } \\
(\mathrm{cm})\end{array}$} & \multirow{2}{*}{$\begin{array}{l}\text { Number } \\
\text { of Lines }\end{array}$} & \multicolumn{2}{|c|}{ Margins } & \multirow{2}{*}{$\begin{array}{l}\text { Space } \\
\text { btw. Col. } \\
(\mathrm{mm})\end{array}$} & \multirow[t]{2}{*}{ Lines (mm) } & \multirow{2}{*}{$\begin{array}{l}\text { Script Size } \\
(\mathrm{mm})\end{array}$} & \multirow{2}{*}{$\begin{array}{l}\text { Visible } \\
\text { Rulings }\end{array}$} \\
\hline & & & $\begin{array}{l}\text { Top } \\
(\mathrm{mm})\end{array}$ & $\begin{array}{l}\text { Bottom } \\
(\mathrm{mm})\end{array}$ & & & & \\
\hline 4Q400 & 12.7 & 21 & $10-13$ & 13 & $\sim 12$ & $\sim 5$ & 2 & $x$ \\
\hline 4Q401 & $?$ & $?$ & 13 & 16 & $\sim 12$ & $6-7$ & 2 & $x$ \\
\hline 4Q402 & $?$ & $?$ & - & - & $\sim 11$ & $\sim 5$ & $\sim 2$ & $x$ \\
\hline 4Q403 & $18+*$ & 50 & $8-11$ & - & 10 & $3-4$ & 1.5 & $x$ \\
\hline 4Q404 & $?$ & $?$ & - & - & - & 6.8 & $2.5-3$ & 0 \\
\hline 4Q405 & $21-22$ & $25^{\star}$ & - & - & 9-16 & $6-9$ & $2.5-3.5$ & $\mathrm{X}$ \\
\hline 4Q406 & $?$ & $?$ & - & - & - & $\sim 7$ & 3 & $\mathrm{X}$ \\
\hline 4Q407 & $?$ & $?$ & - & $13+$ & - & $\sim 7$ & 3 & 0 \\
\hline 11Q17 & $14-19 *$ & $18-25^{\star}$ & - & - & $>12.5$ & $7-8$ & $1.3-2$ & $X^{18}$ \\
\hline Mas $1 \mathrm{k}$ & 21.5 & 26 & $\sim 20$ & $16+$ & 18 & 7 & 3 & $X$ \\
\hline
\end{tabular}

Focused on those five scrolls that allow for at least partial reconstruction, the degree of variation among the material features is remarkable. Compared to the overall corpus of the Dead Sea Scrolls, 4Q405, 11Q17, and Mas 1k are all to be put at the transition between scrolls with medium writing blocks (15-24 lines per column) and such with large writing blocks (25-34 lines per column). ${ }^{19}$ At the same time, the height of all

15 Cf. e. g. Alexander 2006, $14 f$.

16 Only 4Q405, which is one of the oldest of the copies, shows waw as mater lectionis a bit less regularly than the other manuscripts (Eshel et al. [eds.] 1998, 308) and 4Q403 varies the spelling of words more than other copies (ibid., 254f.; see also below, p.75f.).

17 Data from Eshel et al. (eds.) 1998; García Martínez/Tigchelaar/van der Woude (eds.) 1998; Tov 2004; Falk 2014; “`” is used to indicate reconstruction; numbers in italic script are from my own measuring based on the high-definition photographs accessible at The Leon Levy Dead Sea Scrolls Digital Library (www.deadseascrolls.org.il; last accessed: 16.04.2018).

18 Exceptionally clear rulings, obviously applied with reddish ink; cf García Martínez/Tigchelaar/van der Woude (eds.) 1998, 260; Tov 2004, 58.

19 Cf. Tov 2004, 86f.; 4Q405 and 11Q17 are not listed in Tov's synopsis, probably because the number of lines for these manuscripts is reconstructed. 
three manuscripts is of an average size in relation to the number of lines..$^{20} 4 \mathrm{Q} 400$, on the other hand, has a few less lines per column but measures just a bit more than half of these scrolls. Thus, the margins, the script size, ${ }^{21}$ and the interlinear spaces on that scroll are smaller than in the three manuscripts mentioned before. Nevertheless, the writing is easily readable. ${ }^{22}$ In comparison, 4Q403 is completely different. It belongs to a very small group of manuscripts that have fifty or more lines per column. ${ }^{23}$ But as different from all other documents in this group, it is not written on high leather sheets. Its height measures ca. $18 \mathrm{~cm}$. As a result, the writing consists of "minute letters" 24 and the space between lines is very small. This in turn leads to a surpassing number of letter spaces per line, whereas the column width is not unusual. ${ }^{25}$ Additionally, in this manuscript the margins both at the top and between the columns, are very small. Taken together, the outer material features of 4Q403 are rather average, but its writing occupies much of the leather, and is very small and cramped compared both to the other manuscripts of the Songs of the Sabbath Sacrifice and to the overall corpus of the Dead Sea Scrolls. Since the script size is exceptionally small, it must have been written by a trained scribe, and, thus, reading it is arduous but still possible. In addition to these layout-features, the orthography of 4Q403 is a bit less consistent concerning the use of mater lectionis and historical/phonetic spellings than in the other manuscripts of the Širot. ${ }^{26}$ And finally, 4Q403 also shows more scribal interventions than all the other witnesses. In the main fragment, Newsom identified six interlinear corrections ${ }^{27}$ and another six times letters, words, or expressions ${ }^{28}$ that were marked by cancellation dots as mistakes. ${ }^{29}$ Additionally, she found traces of ink at several spots that might or might not be further cancellation dots, ${ }^{30}$ and identified an abundance of minor scribal mistakes that were not corrected in the manuscript. ${ }^{31}$

20 Tov 2004, 84-90 mentions the respective measurements but does not analyze the relation between scroll height and number of lines per column.

21 On the script size of $11 \mathrm{Q} 17$ see below.

22 Cf. Falk 2014, 70.

23 Tov 2004, 89 mentions 7 scrolls. He considers it possible, that a large format is one aspect of de luxe-scrolls and might serve as a hint for the authoritative character of a scroll (ibid., 91.125-129). But 4Q403 hardly belongs to these scrolls, since the only feature it shares with the other scrolls of this group is the high number of lines per column; cf. Falk 2014, 62, n.116.

24 Tov 2004, 17.

25 Cf. Eshel et al. (eds.) 1998, 253. The exceptionally high numbers of letters per line in 4Q403 can be seen e. g. by a comparison between 4Q4031 ii,1-3 and 4Q404 6, which shows lines with only about half as many letters; cf. Eshel et al. (eds.) 1998, 298.

26 Cf. Eshel et al. (eds.) 1998, $254 \mathrm{f}$.

27 They are located in the following columns/lines of fragment 1 i,3,4,19,27; ii,6,24.

28 In fragment $1 \mathrm{i}, 4,34-35,37,42 ; \mathrm{ii}, 12,21$.

29 Cf. Eshel et al. (eds.) 1998, 256-291.

30 Cf. the comments to the following lines i,18,33,37,39; ii,13,31 (Eshel et al. [eds.] 1998, 256-291).

31 Cf. the comments to the following lines ( ${ }^{\star}$ indicates reconstruction) i,1,7,9-10^,30?,31; ii,5; (Eshel et al. [eds.] 1998, 256-291). 
In sum, the scroll 4Q403 seems to be a less diligent copy utilizing the leather sheets at the best with only a minimum focus on lucidity. Thus, the decisive factor during its preparation seems to have been to reduce cost. ${ }^{32}$

Also for the other scrolls, the measurements might indicate the focus of the scribes during their preparation and writing of the scrolls. With a script size and margins just a bit below average, but a decisively smaller height of sheets, the focus of 4Q400 might have been on portability. It stands to reason that a smaller, but longer scroll is easier to be transported than a short scroll with high sheets. ${ }^{33}$ The other three scrolls that allow for evaluation of their overall character (4Q405, 11Q17, and Mas 1k), are of a rather "large and generous format", ${ }^{34}$ thus neither cost nor thoughts about portability seem to have influenced their production. However, 11Q17 stands out among these scrolls in two ways. Firstly, it has a very small script size, comparable to the one found in 4Q403. But at the same time, it shows generous interlinear spaces-as different from 4Q403-and is therefore easily readable. Secondly, this scroll has been meticulously prepared by its scribe: Whereas in all the other scrolls of the Širot that show horizontal-and sometimes vertical-rulings, these were applied with a sharp instrument (“dry-point rulings"), the rulings visible in $11 \mathrm{Q} 17$ were drawn with a special ink, differing from the black ink used for the writing. That detail makes this scroll extraordinary, probably indicating its special value. ${ }^{35}$

Finally, the material aspects mentioned thus far can be evaluated as to whether they can provide clues about ancient reading practices. For 4Q403, both the utilization of the leather sheets and the less diligent copying correspond to the assumption, that the scroll was a "scholar's personal copy for study". ${ }^{36}$ Also, $11 \mathrm{Q} 17$ might count as a manuscript formatted for private-or library-use due to its small script size. However, its exceptional beauty might also indicate some kind of representative function-be it in a private or a public context. ${ }^{37}$ For the other scrolls that allow for further

32 Cf. Falk 2014, 69f., who estimates a width of just $1.25 \mathrm{~m}-11$ columns for a scroll containing the complete collection in this style of writing (compared to e. g. 20-21 columns [3.5-4 m-my estimation based on the available data for column width and space between columns] for 4Q405; cf. Eshel et al. [eds.] 1998, 309-311).

33 Cf. Falk 2014, 69f.

34 Falk 2014, 69, referring only to 4Q405.

$3511 \mathrm{Q} 17$ is one of only very few scrolls which show this feature, cf. Tov 2004, 58.

36 Falk 2014, 70.

37 Since it is debated whether the scrolls found in Qumran cave 11 initially belonged to the same collection as the scrolls from other caves, especially from caves 1 and 4, 11Q17 might have had another socio-cultural background than the other copies of the Širot (for the discussion on the cohesion of the caves see e. g. Pfann 2007; Stökl Ben Ezra 2011; Crawford 2012). Thus, its extraordinary layout could also indicate especially wealthy owner(s). Cf. the observations on the meaning of the aesthetics of scrolls beyond their functional purposes by Johnson 2000, 612-615. However, the editors of 11Q17 note a striking similarity between this scroll and 4Q405 concerning the preserved texts, at least one "questionable reading", and the overall reconstruction; cf. García Martínez/Tigchelaar/van der Woude (eds.) 1998, 266. 
assumptions on their character, it is conceivable that they were intended to be used in a ritual performance. ${ }^{38}$ Considering also the relatively high total number of copies of the Songs of the Sabbath Sacrifice found among the Dead Sea Scrolls, and especially those found in Qumran cave 4, it is also possible that they were used by several participants within a liturgical setting of the yahad. ${ }^{39}$ These assumptions, however, can hardly be more than speculation.

\section{Layout}

From these broader observations on the manuscripts themselves, I'll now turn the focus more to the writing, concretely to the layout of the songs. At first, it can be observed, that the layout of the individual songs has no special features. Whereas it can be debated whether the texts of the compositions follow the rules of (late) Biblical poetry, ${ }^{40}$ their layout is clearly "prosaic" throughout all the manuscripts. ${ }^{41}$ This means that the eventual poetical structures are not at all represented in the layout of the songs, but they are written down as running texts-just like any prose composition. ${ }^{42}$ What is clearly represented in the layout, however, is the transition between two songs, which therefore should be analyzed in detail.

\subsection{Transition Between Two Songs}

Throughout the manuscripts the beginning of every new song is clearly marked. As it is the case with other manuscripts from the Judean Desert, especially those bearing poetic or liturgical compositions, scribes seem to have been rather individualistic in shaping the division between two compositions (tab. 3). ${ }^{43}$ All new songs start in a new line. But the position of that line on the leather sheet and its layout as well as the

38 Cf. Falk 2014, 69f., who appropriately states that such a scribal intention says nothing on whether the scrolls were in fact used in liturgical settings.

39 Cf. Stökl Ben Ezra 2016, 79.

40 Cf. Segert 1988; Davila 2000, 87f.

41 Tov 2004, 167 assumes that a specific poetical layout (stichographic arrangement of poetical units) was confined to those texts considered to be "Biblical", even though not used in all documents belonging to that group (cf. also Tov 2012). Pajunen (in this volume, p. 58) assumes that stichographic layout is related to the clear parallelism of (earlier) "Biblical" psalms. Both would be are applicable to the "prosaic" layout of the Širot.

42 However, there might be a few exceptions, like the one in Mas 1k II,20-22. All these lines begin with “[...] שבע תהלי" ("seven psalms of [...]”) coinciding with the repetitive structure of the text that has seven repetitions of the expression in lines 19-22 (two per line in lines 19-21, one in line 22).

43 The different modes of denoting sense units are described in Tov 2004, 143-154; concerning Psalms and similar compositions see also ibid., $163 \mathrm{f}$. 
layout of the preceding lines vary substantially. Unsurprisingly, songs can begin at the top of a new column. This is the case for the first song ( $4 Q 4001 \mathrm{i}, 1),{ }^{44}$ and also subsequent songs could start on a new column (4Q401 1-2,1). ${ }^{45}$ If they do not start on the top of a column, the last written words of the previous song often end before the left margin of the line, so that an open space emerges at the end of that line (4Q400 $3 \mathrm{ii}, 6$; Mas 1k I,7; 4Q403 1 i,29; 4Q403 1 ii,16). Sometimes a completely blank line precedes the beginning of a new song. In the two extant fragments that show this feature and allow for statements on the line before, the blank line follows an open space at the last line of the preceding text (4Q400 $3 \mathrm{ii}, 7$; 4Q403 $1 \mathrm{ii}, 17) .{ }^{46}$ And finally, in at least one instance, the written text of the first line of a new song is indented (4Q40520 ii,6). Due to the fragmentary character of the manuscripts it cannot always be determined whether just one of these features or a combination of several possibilities has been used. ${ }^{47}$

Since so many manuscripts of the Songs of the Sabbath Sacrifice have been found in cave 4 of Qumran, we can assume, that at least some of them were copies of the same Vorlage $e^{48}$ or even of one another. All the more noticeable is the fact that the layout of the beginning of a new song varies even for one and the same song (see the columns for songs 6,8 , and 12 in tab. 3). The copyists seem to have focused on copying the texts accurately, whereas the layout could have been modified-e. g. according to the purpose of the scroll or its material preconditions. ${ }^{49}$ Additionally, some manuscripts (e.g., 4Q400; 4Q403; 4Q405), which show more than one division between two songs in their extant fragments, reveal that the layout of such a division varied also within one document. Thus, also a single scribe seems to have been rather free in shaping the beginning of a new song. Taken together, there was obviously neither a fixed tradition on how to indicate the transition between two compositions within

44 The beginning of the first song and thereby of the whole composition is only extant in 4Q400probably because that scroll was furled inside out, so that the beginning of the scroll came to be at the most protected position of a stored scroll, cf. Eshel et al. (eds.) 1998, 174. According to Tov 2004, $108 \mathrm{f}$. this fact might indicate an active use of the scroll before its storage.

45 Since this is attested only once and the preceding column is lost, nothing can be said on whether also in this case the last line of the previous song received a special layout. It is also possible, that 4Q401 1-2 shows the beginning of that scroll, since an exceptionally wide margin is visible to the right of the writing block. If this is the case, the composition must have appeared in a smaller extent or a different order than-at least-4Q400; cf. Tov 2004, 110, n. 148.

46 Since in several cases nothing can be said on the end of the previous line (4Q4061,3; 11Q17 VII,8), it is conceivable that a blank line could also occur instead of an open section; cf. Tov 2004, 146-148.164. 47 See the many question marks in table 3 and the footnotes to almost all manuscripts.

48 In some instances, also the text-especially textual mistakes-indicate that some of the extant scrolls were copied from the same "archetype"; cf. e. g. the notes in Eshel et al. (eds.) 1998, 245.263 on a common Vorlage of 4Q405 and Mas 1k and ibid., 264 on a common "archetype" of 4Q403 and 4Q405; cf. also García Martínez/Tigchelaar/van der Woude (eds.) 1998, 266 on similarities between 11Q17 and $4 \mathrm{Q} 405$. However, a systematic analysis of the relationship between the individual manuscripts has yet to be undertaken.

49 This is very common among the Dead Sea Scrolls; cf. Tov 2004, $29 \mathrm{f}$. 
the Songs of the Sabbath Sacrifice, nor did scribes choose one system and use it consistently. A third observation should be added. As said before, the initial words of a new composition are always preceded by at least one line-break. Thus, the only mode of denoting sense units-known from the overall corpus of the Dead Sea Scrolls-not attested in the extant material of the Širot is a "space in the middle of the line ("closed section' in the Masoretic tradition)". ${ }^{50}$ Whereas it cannot be ruled out that the lacking of this layout feature is caused by the fragmentary character of the manuscripts, it goes well with the assumption, that the only important factor concerning sense divisions within the Širot was that the beginning of a new song must be clearly discernable. A free space (closed section) in the middle of a line might have been just too easily be overlooked. In sum, scribes seem to have been free to choose just that mode of sense division that matched best to the layout of the last lines of the preceding song to indicate the beginning of a new song as clearly as possible. ${ }^{51}$

Tab. 3: The layout of the beginning of a new song in the Songs of the Sabbath Sacrifice; manuscripts of songs $1-7$.

\begin{tabular}{|c|c|c|c|c|c|c|}
\hline Song 52 & 1 & $2 ?$ & $4 ?$ & 6 & 6 & 7 \\
\hline \multirow[t]{2}{*}{ Manuscript } & 4Q400 & 4Q400 & 4Q401 & Mas $1 \mathrm{k}$ & 4Q406 & 4Q403 \\
\hline & 1 i,1 & $3 \mathrm{ii}, 8$ & $1-2,1^{54}$ & I,8 & $1,4^{56}$ & $1 \mathrm{i}, 30$ \\
\hline New Column & $x$ & 0 & $x$ & 0 & 0 & 0 \\
\hline $\begin{array}{l}\text { Open Section } \\
\text { (Previous line) }\end{array}$ & - & $x$ & - & $x$ & $?$ & $x$ \\
\hline Blank line & - & $x$ & - & 0 & $x$ & 0 \\
\hline $\begin{array}{l}\text { Indentation of } \\
\text { new line }\end{array}$ & $0^{53}$ & 0 & 0 & $0^{55}$ & $0 ?$ & 0 \\
\hline
\end{tabular}

50 Tov 2004, 145.

51 That applies even to 4Q403, the manuscript that was produced with the focus on reducing costs-as seen above (p. 76). Although, an open space should have been sufficient to indicate the beginning of a new song, in fragment $1 \mathrm{ii}, 18$, that manuscript shows a blank line before the beginning of song 8-maybe because in the preceding line the writing occupied more than half of the line.

52 For those songs not listed in the table, the first line is not extant.

53 The beginning of the line is reconstructed, but the editor names several reasons why the line should have begun at the right margin, cf. Eshel et al. (eds.) 1998, 178f.

54 Fragment 1 bears the beginning of a song. But only by combining it with fragment 2 it can be identified as the fourth song with some certainty, cf. Eshel et al. (eds.) 1998, $199 \mathrm{f}$.

55 The beginning of the line is reconstructed. Considerations of space, however, do not allow for indentation; cf. for the reconstruction Eshel et al. (eds.) 1998, 243.

56 Obviously, a new song begins on this fragment. Assigning it to song 6, however, is debatable, cf. Eshel et al. (eds.) 1998, 395f. In her earlier edition C. Newsom regarded an ascription to song 8 as more probable (Newsom [ed.] 1985, 356). 
Tab. 3: continued; manuscripts of songs 7-12.

\begin{tabular}{|c|c|c|c|c|c|c|}
\hline Song & 7 & 8 & 8 & 8 & 12 & 12 \\
\hline \multirow[t]{2}{*}{ Manuscript } & 4Q404 & 4Q403 & 4Q405 & 11Q17 & 4Q405 & 11Q17 \\
\hline & $3,2^{57}$ & $1 \mathrm{ii}, 18$ & $8 b, 1^{58}$ & $3(11,4)^{59}$ & $20 \mathrm{ii}, 6$ & $16-18(\mathrm{VII}, 9)$ \\
\hline New Column & 0 & 0 & $?$ & $0 ?$ & 0 & 0 \\
\hline $\begin{array}{l}\text { Open Section } \\
\text { (Previous line) }\end{array}$ & $X ?$ & $\mathrm{x}$ & $?$ & $?$ & $?^{60}$ & $?$ \\
\hline Blank line & 0 & $\mathrm{x}$ & $?$ & $?$ & 0 & $\mathrm{x}$ \\
\hline $\begin{array}{l}\text { Indentation of } \\
\text { new line }\end{array}$ & $?$ & 0 & $X ?$ & $X ?$ & $\mathrm{x}$ & $0^{61}$ \\
\hline
\end{tabular}

In a last step, this layout feature is to be correlated to the textual evidence of the songs. Every song begins with a superscription. These headings are framed rather uniformly. ${ }^{62}$ They always begin with "למשכיל" ("for the instructor") as a directive that can similarly be found in the superscriptions of Biblical psalms. ${ }^{63}$ This attribution is followed by the title "שיר עולת השבת" ("song of the burnt offering of the Sabbath")which also gave the composition its name-and a number indicating the position of the respective Sabbath in the year and, assumingly, at the same time the number of the song in the composition. The third element of the heading is a date formula consisting of a day and a month. It places the Sabbaths within a solar calendar with fixed dates-364 days per year, every year beginning on a Wednesday-that is

57 The fragment is too small to say anything about the layout of the division between song 6 and 7. But since there seem to be traces of ink above the initial line of song 7 , it is possible that there was a (small) open section at the end of the last line of song 6 . The indentation of the first line of the new song is less probable; cf. for the reconstruction Eshel et al. (eds.) 1998, 296.

58 The fragment contains only parts of the first two lines of the song. Thus, already assigning it to song 8 is debatable. Additionally, nothing can be said on the preceding lines. The editor assumes the first line to be indented, cf. Eshel et al. (eds.) 1998, 325.

59 The fragment contains only parts of the first four lines of the song. Thus, again nothing can be said on the preceding lines. The editor assumes the song to start in line 4 of the column and considers indentation probable, cf. García Martínez/Tigchelaar/van der Woude (eds.) 1998, $269 f$.

60 The previous line is only partially extant. Thus, it cannot be ruled out that it contained a (small) open section at the end; cf. Eshel et al. (eds.) 1998, 345.

61 The right margin is not extant. But since the end of the first line of the new song and the beginning of its second line can be reconstructed as showing words that immediately follow each other in $4 \mathrm{Q} 405$ $20 \mathrm{ii}, 7$, the first line was rather not indented; cf. for the reconstruction García Martínez/Tigchelaar/van der Woude (eds.) 1998, 283.

62 The complete superscription is extant only in 4Q403 $1 \mathrm{i}, 30$ (song 7).

63 Cf. Eshel et al. (eds.) 1998, 179. 
broadly attested for the late Second Temple Period and especially within the Dead Sea Scrolls. ${ }^{64}$ Thus, the headings of the songs indicate that every song is meant for a special day, concretely one of the Sabbaths of the first quarter of the year. ${ }^{65}$ The layout features described here support the idea, that the composition was not meant to be read at a stretch, but rather reading or reciting the composition could have happened in parts. Therefore, the demarcated beginning of a new song could have signaled to the reader to stop reading here and continue it the following week.

\subsection{Vacats}

While the sense divisions between individual songs vary significantly concerning the shaping, they completely coincide concerning the placement of the divisions. This is hardly surprising since the beginning of each new composition is clearly indicated on the level of the text by the superscriptions. In addition to these clearly marked transitions between two songs, empty spaces (vacats) and even some completely blank lines can also be found within the individual compositions. ${ }^{66}$ Especially the two blank lines (4Q403 1i,15; 4Q405 $3 \mathrm{ii}, 12$ ) resemble-from their representation in the editionthe division between two compositions. Although they both occur in the same part of the overall composition, i. e. song 6, they do not appear at the same place within this composition. They both lack a plausible explanation based on the texts because they are located in the middle of sentences. Looking at the photographs of fragment 3 from 4Q405, however, I would query whether it is at all suitable to describe the phenomenon as a vacat line. In this fragment-as in the others sorted in the first group of fragments of this manuscript by the editor ${ }^{67}$-dry lines are visible but sometimes disregarded, leading to varying line spacing. This is exactly what happens in fragment 3, lines $11-14 .^{68}$ Thus, what can be seen here, is better to be described as sloppy scribal practice than as a vacat line. The case for 4Q403 is in a way different. As we saw above, the main concern for the scribe of this scroll was to save space. Therefore, a line left blank is all the more striking. Nevertheless, here again, we see not just one

64 Cf. for a review on the respective literature Albani 1997; for the calendars within the Dead Sea Scrolls VanderKam 1998.

65 As Newsom showed, the composition consisted only of these thirteen songs and did not extend to all 52 Sabbaths of the year (Newsom [ed.] 1985, 5). Additionally, several thematic correspondences with the festival cycle of the first quarter of the year indicate, that the Širot were not intended to be repeated for the other three quarters; cf. ibid., 19 and Charlesworth/Newsom 1999, 4 against e. g. Maier 1992, 544.

66 Completely blank lines not followed by the beginning of a new song appear in 4Q403 $1 \mathrm{i}, 15$ and 4Q405 3 ii,12. Smaller vacats are more widespread: 4Q400 1 i,6; 1 i,8[?]; 1 i,12; 1 i,16; 1 ii,8; 1 ii,12; 1 ii,14[?]; 1 ii,16; 2,5; Mas 1k II,23; 4Q403 1 i,6; 1 ii,32; 4Q405 13,2; 23 i,13; 23 ii,7; 23 ii,12; 11Q17 12,9; 17,2.

67 I. e. fragments 1-10, cf. Eshel et al. (eds.) 1998, $307 \mathrm{f}$.

68 Cf. Eshel et al. (eds.) 1998, 320. 
blank line, but also the line before leaves a larger interlinear space than the average within this manuscript. Since the leather is badly damaged in this part, it cannot be ruled out that there were material problems here, already when the writing was applied. But regarding the high number of scribal errors and corrections within this manuscript, a scribal mistake is conceivable, as well. ${ }^{69}$

The smaller vacats, however, should be discussed in their own right. Some of them are obviously placed at the beginning of new sentences or even larger units within one song. ${ }^{70}$ Unfortunately, for nearly all those parts of the manuscripts that show a vacat, no second witness is extant. The only exception might be the small vacat in 4Q403 1 $\mathrm{i}, 6$, that can also be reconstructed in Mas $1 \mathrm{k}$ II, $16 .{ }^{71}$ But this evidence-especially since it is based on reconstruction-is not enough to say anything on whether the scribes copied these subordinate sense divisions or whether each scribe just added them due to his own interpretation of the text. In sum, it can be concluded, that-at least some of-the scribes ${ }^{72}$ who wrote down the Songs of the Sabbath Sacrifice provided their readers non-textual clues about the structure of the text and thereby influenced the reading of their manuscripts. Whether this happened while writing down those copies that were found in Qumran and Masada or already existed in their Vorlage(n) can no longer be discerned.

\subsection{The Name of God}

In early Judaism - ca. 3rd or 2nd century BCE-people increasingly avoided to speak out the name of God represented by the so-called tetragrammaton יהוה ("yhwh"). This can be seen in many Dead Sea Scrolls, which avoid the use of the term and substitute it by other expressions, represent the tetragrammaton in Paleo-Hebrew letters, or replace it by four points, the so-called tetrapuncta-the latter two usually in "Biblical" texts or passages. ${ }^{74}$ In some scrolls-especially those characterized as yahadic-this feature is also transferred to other names or representations of the deity, especially to the terms "אלוהים" and "אלוה" (both meaning "God"). ${ }^{75}$ Since there is no evidence that

69 Cf. Eshel et al. (eds.) 1998, 259.

70 Cf. Eshel et al. (eds.) 1998, 182.186 .190 on some of the instances from 4 Q400 (1 i,16; 1 ii,12; 2,5). The same can be said on the smaller vacats from $4 \mathrm{Q} 403$ and Mas $1 \mathrm{k}$, on most of those from 4Q405 (13,2; 23 ii,7; 23 ii,12), and maybe also on 11Q17 17,2.

71 Cf. Charlesworth/Newsom 1999, 136 n. 32.

72 Vacats can be found in all five scrolls from which major fragments are extant. From the others only rather small fragments are extant, so that the absence of vacats is hardly surprising.

73 Cf. Green 2000, $498 f$.

74 Cf. Tov 2004, 218-221.

75 Cf. Tov 2004, 238f.; Green 2000, 497f. points out, that the presentation of divine names is rather inconsistent both within individual documents and the overall corpus of the Dead Sea Scrolls. 
also these other names were avoided in oral texts, the marking of these terms might just indicate that the respective term is used as a substitute for the tetragrammaton. ${ }^{76}$

In the Songs of the Sabbath Sacrifice the deity is never called by the tetragrammaton. Instead, both the terms "אלוהים" "אל" ("God") are used. " ${ }^{77}$ In nearly all the manuscripts, neither of these words received any special treatment. In a way, this makes reconstructions and translations of the extant text fragments more complicated, because both terms are also used to denote subordinate god-like beings. While in the case of "אל" a clear distinction can be made from the number used-singular for God, plural for subordinate beings-the term "אלוהים", which is originally a plural form, is used for both. Thus, in understanding and translating the texts, one always has to decide whether God or these subordinate beings are meant-not always an easy task, especially if the literary context is mostly lost. However, there again is one exception. Two of the fragments of 4Q406 show the word אלוהים or parts of it in Paleo-Hebrew letters. ${ }^{78}$ The scribe probably presented the expression in this special way to underline its sacred character. ${ }^{79}$ Albeit,-if the reconstruction of fragment 1 is correct ${ }^{80}$-the scribe wrote not only those instances of the word in Paleo-Hebrew letters that indicated the deity, but at least once also used the script in the other case, representing subordinate celestial beings. Thus, readers might in principle have realized the sacred character of the term from this manuscript more easily but still got no help by the layout in discerning the name of the deity from the plural-form of godlike beings. Accordingly, it can be concluded that the easy identification of a sacred term indicating the deity was no primary concern for all the scribes that produced the copies of the Songs of the Sabbath Sacrifice. Moreover, the almost consistent presence of "אלוהים"-and "אל"-in plain script could indicate, that this term was not used as replacement of an older tetragrammaton but represented the deity in the Širot from their first edition onwards. Carried on to the level of readers, this might indicate that the word "אלוהים" was just ordinarily read out in the recitation of the Širot and, thus, received no special treatment also in the oral performance.

76 Cf. Green 2000, 505.

77 The occurrence of this term is often taken as an indication of the non-/pre-Qumran origin of the composition, since the expression is broadly avoided in the yahadic literature; cf. e. g. Charlesworth/ Newsom 1999, 4 f.

78 Cf. Eshel et al. (eds.) 1998, 395-398. 4Q406 is severely damaged by the ink used for the writing. In consequence, the writing on the small extant fragments must be reconstructed from the holes left by the destructive ink (see above fn.10).

79 Cf. on the phenomenon e. g. Siegel 1971.

80 Cf. Eshel et al. (eds.) 1998, 396. 


\section{Metatextual Clues}

In a last step, also the text of the composition should be analyzed in light of the question about how the Songs of the Sabbath Sacrifice were-supposed to be-read. Are there any indications within the text about ancient reading practices? Or-in other words-can the Širot be interpreted as self-referential metatexts, written entities that reflect their own character as texts? ${ }^{81}$

The first element, that might give a hint is the directive "למשכיל" ("for the instructor") in the superscriptions of the individual songs. This expression is reminiscent of the Biblical psalm headings in a twofold way. Firstly, the term "משכיל" itself is used thirteen times in the superscriptions. Yet in contrast to its use in the Širot, within the Biblical psalms, it is used without the preposition "ל" ("for") and is therefore rather to be understood as a characterization of the respective psalm itself. ${ }^{82}$ Therefore, as a second way, the directive resembles those parts of the psalm headings that are also

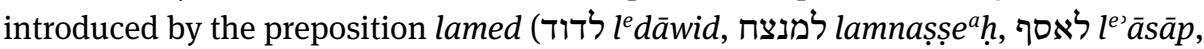
libnê qorah, ....). Although these terms probably should not be measured by the same yardstick, and their interpretations hover between statements of authorship, school-assignments, performance-instructions, guidelines for interpretation, and the beginning of collections, ${ }^{83}$ one possible reading for all the expressions is the dedication to a person or group-however that is to be understood. In line with this, also the term "למשכיל" at the beginning of each of the Songs of the Sabbath Sacrifice can be interpreted as a dedication. ${ }^{84}$ In all likelihood, the figure pointed at by this expression, is the one described with the very same term also in other ("non-Biblical"/“yahadic") compositions from the Judean Desert. According to the evidence especially from the Rule of the Community the mașkîl was a major office within the yahad (e. g. 1QS 3:13; 9:12-10:5), whose holder was not only wise himself but had to strive for nurturing the wisdom-understood as the true interpretation of the Torah-of other members by didactic instructions, and thereby exerted as a leader of the community as a whole. ${ }^{85}$ Concerning the Songs of the Sabbath Sacrifice, the dedication to that central figure could indicate that he played a major role in the liturgical execution of the Širot. ${ }^{86}$ Whether or not the dedication can be taken as a reference to the actual

81 The term "metatext" is used here in accordance with its use within the CRC 933. Cf. Hilgert 2010, 98; Gertz et al. 2015; Focken/Ott (eds.) 2016.

82 Whether the term focuses on the content of the psalm (e. g. Kraus 1989, 19f.) or on its form (or its performance; cf. Koenen 1991) is still debated, but insignificant in the present context.

83 Cf. e. g. the summary by Mroczek 2016, 58-61.

84 Cf. Charlesworth/Newsom 1999, 4.

85 Cf. Newsom 1990; Rietz 2007, 46f.; in a more recent publication (Charlesworth/Newsom 1999, 5) Newsom is less certain and mentions also a second possibility as to which "למשכיל" could mean: "to the one who is wise" in a more general way.

86 Cf. Newsom 1990, 380; Elgvin 2013, 805. 
reading practice of the composition, this cannot be decided. Anyways, the attribution to that leading figure in the community grants the Širot authority within the yahad.

The overall scope of the composition as well as one textual detail indicate that it was not just the mașkîl who was intended to read or recite the Širot but a larger group. ${ }^{87}$ In one single passage ( 4 Q400 2,5-8), originating probably from the second song, first person plural grammatical forms are extant. ${ }^{88}$ They refer to a group which compares its human priesthood and worship to the angelic described before. Since the grammatical form here is a plural form, the intended readers/reciters were likely to have been a worshipping community. ${ }^{89}$

Furthermore, also the second term of the superscriptions might be interesting as a metatextual reference to the Širot. The word "שיר" ("song") is known from its Biblical use especially in the Psalms and the Books of Chronicles and Ezra-Nehemiah. ${ }^{90}$ Leaving aside all discussions on its meaning concerning genre etc., the word is certainly connected to oral-musical performance. ${ }^{91}$ In the Songs of the Sabbath Sacrifice the term is restricted to the superscriptions, just as in the Biblical Song of Songs. Whereas neither the earthly participants nor the celestial beings are reported to "sing" (שיר) anything, ${ }^{92}$ other terms like "praise" (ידה/הלל), "sing praise” (זמר), "laud" (שבח), "bless" (ברך) or "rejoice" (רנן) are used frequently. Thus, the active voice is a common motive within the composition, ${ }^{93}$ and the use of "שיר" in the heading might very well indicate, that the Širot were indeed meant to be sung. If they actually were, however, is another question that cannot be answered on the extant material.

Finally, the last element of the headings should be considered, the formula "עולת השבת" ("of the burnt offering of the xth Sabbath”). This phrasing might invoke the impression of an execution of sacrifices accompanied by hymns-here the Songs of the Sabbath sacrifice-as described in Second Temple Literature (cf. 2 Chr 29:27-28; Sir 50:14-19). ${ }^{94}$ However, apart from the superscriptions, there is hardly any connection to sacrificial cult within the composition. ${ }^{95}$ Therefore, Newsom's suggestion to understand the formula rather as a designation of time is worth considering. ${ }^{96}$ The connection of the Širot to the Sabbath sacrifice would then not be factual but temporal. That is, the prayer and the act of mystical self-transcending to the heavenly sanctuary expressed by the composition could profit from an established special

87 Cf. e. g. Lieber 2004, 57f. et passim.

88 Cf. Eshel et al. (eds.) 1998, $187 \mathrm{f}$.

89 Cf. Newsom (ed.) 1985, 17. Although the content of the praise (of earthly and celestial beings) is not described but frequently demanded, the Širot are hymnal praise themselves, cf. Ego 2015, 896f.

90 Cf. Fabry et al. 1993, 1263.

91 Cf. Fabry et al. 1993, 1269-1282.

92 Cf. Schuller 2016, 909.

93 Cf. Lieber 2004, 51f.

94 Cf. Newsom (ed.) 1985, 18.

95 Cf. Newsom (ed.) 1985, $18 \mathrm{f}$.

96 Newsom (ed.) 1985, $19 f$. 
connection between heaven and earth during Sabbath and especially during the time of the sacrifice. Transferred to the question of reading practices, this part of the heading would provide further information as to when the Širot were read or recited, even if it cannot be interpreted as data on the particulars of the performance.

\section{Conclusion}

Taking together all three levels of the analysis above, the manuscripts, their layout, and the metatextual elements, a fairly clear picture of the ancient reading practices of the Songs of the Sabbath Sacrifice emerges. Whereas the texts and their layout give hints about the intended reading and reception of the Širot, the outer data on the manuscripts might indicate their actual use. Thus, all three dimensions reveal that it is at least possible that the composition was recited in a ritual setting. Both the arrangement of the text on the scrolls (at least on 4Q405, Mas 1k, and maybe 11Q17), the clearly discernable songs within the individual manuscripts, and the metatextual understanding of the superscriptions undergird this interpretation. Moreover, the clear distinction between the individual songs as well as the dating in the headings indicate that the Širot were meant to be read or recited in parts, one song for each of the first thirteen Sabbaths of the year. Thirdly, there are also hints concerning the persons involved in reading the cycle. It is, on the one hand, a leading figure, the mașkîl, mentioned in every superscription and maybe the owner of the "scholar's copy" 4Q403, and, on the other hand, a group of co-celebrators, represented within the text in the infrequently used first person plural forms and possibly making use of the high number of copies found in Qumran. Additionally, the further observations on the layout might indicate, that readers made use of structuring signals within the individual songs, and that the designation for God used in the composition (אלוהים) very likely received no special treatment in oral performance. But, of course, these further assumptions require the basic theory that the Songs of the Sabbath Sacrifice actually were read out-in a liturgical context-to be true, and are thus of a lower level of likeliness.

In the end, the only question that remains unanswered from all three directions of analysis is the one, why the composition covered just the first quarter of the year and not all the Sabbaths, as presumed by the small metatextual passage David's compositions in the Great Psalms Scroll (11Q5):

$$
\text { ושירב לשורר לפני המזבח על עולת התמיד לכול יום ויום לכול שיר ומי השנה ארבעה וששים ושלוש מאות }
$$

And [David wrote] song(s) to sing before the altar over the burnt offerings, the daily one, day by day for all days of the year, 364, and for the offering of the Sabbaths, $52 \mathrm{song}(\mathrm{s})$. 


\section{Bibliography}

Accordance ${ }^{\circledR} 11$ (2017), OakTree Software, Inc., Altamonte Springs.

Albani, Matthias (1997), "Zur Rekonstruktion eines verdrängten Konzepts: Der 364-Tage-Kalender in der gegenwärtigen Forschung”, in: Matthias Albani, Jörg Frey and Armin Lange (eds.), Studies in the Book of Jubilees (Texte und Studien zum Antiken Judentum 65), Tübingen, 79-125.

Alexander, Philip S. (2006), The Mystical Texts: Songs of the Sabbath Sacrifice and Related Manuscripts (Library of Second Temple Studies 61), London/New York.

Charlesworth, James H./Newsom, Carol Ann (1999), The Dead Sea Scrolls. Hebrew, Aramaic, and Greek Texts with English Translations. Angelic Liturgy: Songs of the Sabbath Sacrifice (The Princeton Theological Seminary Dead Sea Scrolls Project 4b), Tübingen.

Crawford, Sidnie White (2012), "Qumran: Caves, Scrolls, and Buildings”, in: Eric F. Mason et al. (eds.), A Teacher for All Generations. Essays in Honor of James C. VanderKam. Volume One (Supplements to the Journal for the Study of Judaism 153), Leiden, 253-273.

Davila, James R. (2000), Liturgical Works (Eerdmans Commentaries on the Dead Sea Scrolls 6), Grand Rapids.

Ego, Beate (2015), “Der Gottesdienst der Engel - Von den biblischen Psalmen zur jüdischen Mystik. Traditionskritische Überlegungen zu den Sabbatopferliedern von Qumran”, in: Theologische Literaturzeitung 140 (9), 886-901.

Elgvin, Torleif (2013), Art. "משכיל", in: Heinz-Josef Fabry and Ulrich Dahmen (eds.), Theologisches Wörterbuch zu den Qumrantexten 2, Stuttgart et al., 802-806.

Eshel, Esther/Eshel, Hanan/Newsom, Carol/Nitzan, Bilhah/Schuller, Eileen/Yardeni, Ada (eds.) (1998), Qumran Cave 4. VI Poetical and Liturgical Texts, Part 1 (Discoveries in the Judaean Desert 11), Oxford.

Fabry, Heinz-Josef/Brunert, Gunild/Kleer, Martin/Steins, Georg (1993), Art. “שיר", in: Heinz-Josef Fabry and Helmer Ringgren (eds.), Theologisches Wörterbuch zum Alten Testament 7, Stuttgart et al., 1259-1295.

Falk, Daniel K. (2014), “Material Aspects of Prayer Manuscripts at Qumran”, in: Clemens Leonhard and Hermut Löhr (eds.), Literature or Liturgy? Early Christian Hymns and Prayers in their Literary and Liturgical Context in Antiquity (Wissenschaftliche Untersuchungen zum Neuen Testament II 363), Tübingen, 33-87.

Focken, Friedrich-Emanuel/Ott, Michael R. (eds.) (2016), Metatexte: Erzählungen von schrifttragenden Artefakten in der alttestamentlichen und mittelalterlichen Literatur (Materiale Textkulturen 15), Berlin/Boston.

Frese, Tobias/Keil, Wilfried E./Krüger, Kristina (eds.) (2014), Verborgen, unsichtbar, unlesbar. Zur Problematik restringierter Schriftpräsenz (Materiale Textkulturen 2), Berlin/Boston.

García Martínez, Florentino/Tigchelaar, Eibert J. C./van der Woude, Adam S. (eds.) (1998), Qumran Cave 11. I/ 11Q2-18, 11Q20-31 (Discoveries in the Judaean Desert 23), Oxford.

Gertz, Jan Christian/Krabbes, Frank/Noller, Eva Marie/Opdenhoff, Fanny (2015), “Metatext(ualität)", in: Thomas Meier, Michael R. Ott and Rebecca Sauer (eds.), Materiale Textkulturen. KonzepteMaterialien - Praktiken (Materiale Textkulturen 1), Berlin/Boston, 207-218.

Green, Dennis (2000), “Divine Names: Rabbinic and Qumran Scribal Techniques”, in: Lawrence H. Schiffman, Emanuel Tov and James C. VanderKam (eds.), The Dead Sea Scrolls Fifty Years after their Discovery. Proceedings of the Jerusalem Congress, July 20-25, 1997, Jerusalem, 497-511.

Hilgert, Markus (2010), “'Text-Anthropologie’: Die Erforschung von Materialität und Präsenz des Geschriebenen als hermeneutische Strategie", in: Mitteilungen der Deutschen Orient-Gesellschaft zu Berlin 142, 87-126.

Johnson, William A. (2000), "Toward a Sociology of Reading in Classical Antiquity", in: The American Journal of Philology 121 (4), 593-627. 
Koenen, Klaus (1991), “Maśkîl - 'Wechselgesang’. Eine neue Deutung zu einem Begriff der Psalmenüberschriften”, in: Zeitschrift für die alttestamentliche Wissenschaft 103 (1), 109-112.

Kraus, Hans-Joachim (1989), Psalmen (Biblischer Kommentar Altes Testament XV/1-2), Neukirchen-Vluyn.

Lieber, Andrea (2004), "Voice and Vision: Song as a Vehicle fo Ecstatic Experience in Songs of the Sabbath Sacrifice", in: Craig A. Evans (ed.), Of Scribes and Sages: Early Jewish Interpretation and Transmission of Scripture 2: Later Versions and Traditions, London/New York, 51-58.

Maier, Johann (1992), "Shîrê 'Ôlat hash-Shabbat. Some Observations on their Calendric Implications and on their Style", in: Julio Trebolle Barrera and Luis Vegas Montaner (eds.), The Madrid Qumran Congress. Proceedings of the International Congress on the Dead Sea Scrolls (Madrid 18-21 March, 1991) (Studies on the Texts of the Desert of Judah 11/2), Leiden/Madrid, 543-560.

Mroczek, Eva (2016), The Literary Imagination in Jewish Antiquity, New York.

Newsom, Carol Ann (ed.) (1985), Songs of the Sabbath Sacrifice. A Critical Edition (Harvard Semitic Studies 27), Atlanta.

Newsom, Carol Ann (1990), "The Sage in the Literature of Qumran: The Functions of the Maśkîl", in: John G. Gammie and Leo G. Perdue (eds.), The Sage in Israel and the Ancient Near East, Winona Lake, 373-382.

Pfann, Stephen (2007), “Reassessing the Judean Desert Caves: Libraries, Archives, Genizas and Hiding Places", in: Bulletin of the Anglo-Israel Archaeological Society 25, 147-170.

Rietz, Henry W. Morisada (2007), "Identifying Compositions and Traditions of the Qumran Community: The Songs of the Sabbath Sacrifice as a Test Case”, in: Michael Thomas Davis and Brent A. Strawn (eds.), Qumran Studies. New Approaches, New Questions, Grand Rapids, 29-52.

Schuller, Eileen M. (2016), Art. "שיר", in: Heinz-Josef Fabry and Ulrich Dahmen (eds.), Theologisches Wörterbuch zu den Qumrantexten 3, Stuttgart, 907-911.

Segert, Stanislav (1988), "Observations on Poetic Structures in the Songs of the Sabbath Sacrifice", in: Revue de Qumran 13 (1), 215-223.

Siegel, Jonathan P. (1971), "The Employment of Palaeo-Hebrew Characters for the Divine Names at Qumran in the Light of Tannaitic Sources”, in: Hebrew Union College Annual 42, 159-172.

Snyder, H. Gregory (2000), "Naughts and Crosses: Pesher Manuscripts and their Significance for Reading Practices at Qumran”, in: Dead Sea Discoveries 7 (1), 26-48.

Stökl Ben Ezra, Daniel (2011), “Wie viele Bibliotheken gab es in Qumran”, in: Jörg Frey, Carsten Claußen and Nadine Kessler (eds.), Qumran und die Archäologie. Texte und Kontexte (Wissenschaftliche Untersuchungen zum Neuen Testament 278), Tübingen, 327-346.

Stökl Ben Ezra, Daniel (2016), “Bücherlesen im Jachad Qumrans. Himmlische Bücher zwischen Katechese, kollektivem Studium und esoterischer Geheimschrift", in: Friedrich-Emanuel Focken and Michael R. Ott (eds.), Metatexte. Erzählungen von schrifttragenden Artefakten in der alttestamentlichen und mittelalterlichen Literatur (Materiale Textkulturen 15), Berlin/Boston, 75-96.

The Leon Levy Dead Sea Scrolls Digital Library <www.deadseascrolls.org.il> (last accessed: 16.04.2018).

Tov, Emanuel (2004), Scribal Practices and Approaches Reflected in the Texts Found in the Judean Desert (Studies on the Texts of the Desert of Judah 54), Leiden/Boston.

Tov, Emanuel (2012), "The Background of the Stichometric Arrangements of Poetry in the Judean Desert Scrolls", in: Jeremy Penner, Ken M. Penner and Cecilia Wassen (eds.), Prayer and Poetry in the Dead Sea Scrolls and Related Literature (Studies on the Texts of the Desert of Judah 98), Leiden/Boston, 409-420.

VanderKam, James C. (1998), Calendars in the Dead Sea Scrolls. Measuring Time (The Literature of the Dead Sea Scrolls 3), London/New York. 